\title{
Bilateral conjunctival pediatric follicular lymphoma
}

\author{
Alia Nazarullah ${ }^{1} \cdot$ Luke Dietz $^{2} \cdot$ Kenneth Wright $^{2} \cdot$ Serhan Alkan $^{1} \cdot$ Qin Huang ${ }^{1}$
}

Received: 26 June 2015 / Accepted: 22 September 2015 /Published online: 30 September 2015

(C) Springer-Verlag Berlin Heidelberg 2015

\begin{abstract}
Follicular lymphoma (FL) is the most common type of B cell non-Hodgkin lymphoma in Western counties. FL is usually seen in adults and is very uncommon in pediatric population. Pediatric follicular lymphoma (PFL) is a rare indolent lymphoma characteristically seen in pediatric population, usually involving cervical lymph nodes, Waldeyer ring, and testis. They pose significant diagnostic challenges due to morphologic overlap with much more common florid follicular hyperplasia and lack of typical $t(14 ; 18) \operatorname{IgH} / B C L 2$ fusion and BCL-2 protein expression. We present the case of a 10year-old male with bilateral conjunctival nodules, showing characteristic morphologic and immunophenotypic features of PFL with demonstrated clonal B cell immunoglobulin heavy chain gene rearrangement. Of note, the neoplastic cells expressed MUM1, MYC, and IgM, suggestive of a different disease pathogenesis from adult FL.
\end{abstract}

Keywords Pediatric · Follicular · Lymphoma · Conjunctival · Bilateral

\section{Background}

Follicular lymphoma is the one of the most common nonHodgkin lymphomas in adults; however, it is very rare in the

Qin Huang

qin.huang@cshs.org

1 Department of Pathology \& Laboratory Medicine, Cedars-Sinai Medical Center, 8700 Beverly Boulevard, Los Angeles, CA 90048, USA

2 Department of Ophthalmology, Cedars-Sinai Medical Center, 8700 Beverly Boulevard, Los Angeles, CA 90048, USA pediatric population. A subtype of follicular lymphoma - pediatric follicular lymphoma (PFL), is described in the World Health Organization, 2008 edition and occurs almost exclusively in children and young adults [1]. It is a distinct entity, which lacks the typical $t(14 ; 18) \operatorname{IgH} / B C L 2$ fusion and BCL-2 expression seen in usual follicular lymphoma, and shows an indolent clinical behavior despite high-grade morphologic features. They usually occur in the head and neck region, involving lymph nodes and the Waldeyer ring or sometimes extranodal sites like testis [2]. Lack of definite diagnostic criteria and differentiation from those with much more common florid follicular hyperplasia in childhood population poses significant challenges in making the accurate diagnosis. Conjunctival involvement of PFL has rarely been reported [3-5], and bilateral conjunctival presentation is even rare [6], with this being only the second reported case in literature.

\section{Clinical history}

A 10-year-old African American boy presented to the pediatric ophthalmology office with a pink lesion near the left caruncle for a few months according to the patient's mother, who had become concerned due to more recent growth. The patient reported occasional foreign body sensation and itch but denied significant pain, tearing, or discharge. He had no previous eye trauma or surgery and no personal or noteworthy family medical history. On slit-lamp microscopic examination he was found to have a $6.2 \mathrm{~mm} \times 4.3 \mathrm{~mm}$ pink mobile nodular lesion near the left caruncle with a similar-appearing $4.8 \times 2.5 \mathrm{~mm}$ nodular lesion near the right caruncle (Fig. 1(A1-A2)). His visual acuity was normal, as was the remainder of his anterior and posterior segment examinations. Both lesions were completely excised under general anesthesia with 1-2 mm margins on all sides and submitted for histopathologic examination. 
Fig. 1 Gross photographs and histologic features of conjunctival lesions: left eye $(A 1)$ and right eye (A2). Hematoxylin and eosin stained sections of the conjunctival lesions: large expanded follicles in left eye, $\times 2$ (A3) and right eye, $\times 10(A 4)$. The left eye also shows multiple irregular smaller follicles, $\times 20$ (A5). High-power view of the sheets of monomorphic large atypical cells within the follicles, $\times 100(A 6)$

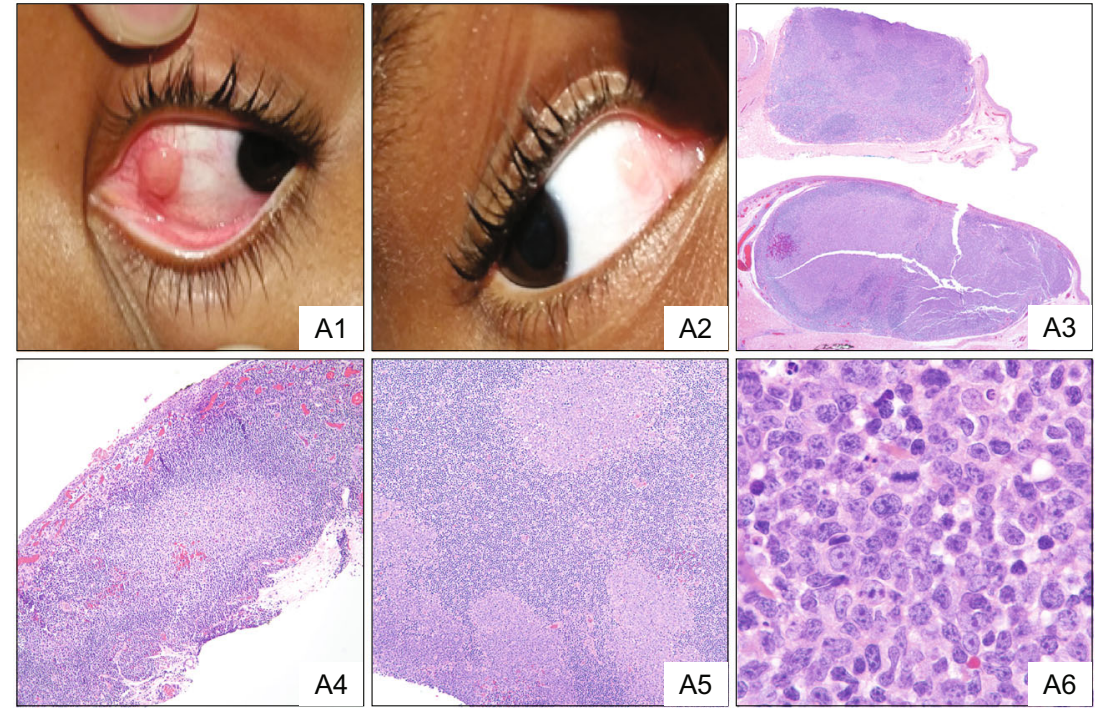

\section{Materials and methods}

The excisional biopsy specimens were formalin-fixed, paraffin-embedded, and stained with hematoxylin and eosin stain. Immunohistochemical stains were performed on a Bond III instrument (Leica Microsystems, Buffalo Grove, IL) and a Benchmark ULTRA system (Ventana, Tuczon, AZ), as per the manufacturer's instructions, using the following primary antibodies: CD3, CD20, CD10, BCL6, BCL2, Ki-67, CD21, MUM1, MYC, and P53. EBV encoding RNA (EBER) in situ hybridization was also performed. B cell immunoglobulin heavy chain $\operatorname{IgH}$ and kappa light chain $\operatorname{IgK}$ gene clonality assays were performed on paraffin-embedded tissue using the $I G H+I G K$ B Cell Gene Clonality Assay (Invivoscribe, San Diego, CA) on the GeneAmp PCR System 9700 and 3500 Genetic Analyzer (Applied Biosystems/Life Technologies, Grand Island, NY). Interphase fluorescent in situ hybridization (FISH) analyses were performed on paraffin tissue using Abbott molecular probes specific for $t(14 ; 18) I G H /$ $B C L 2$ fusion, BCL6 (3q27), and $C M Y C$ (8q24) genes.

\section{Results}

The conjunctival lesion in the left eye demonstrated a lymphoid proliferation with markedly expanded and distorted atypical follicles/nodules with attenuated to absent mantle zones. The neoplastic follicles contained a monomorphic population of large atypical lymphoid cells admixed with few tingible-body macrophages, numerous mitotic figures, and apoptotic debris (Fig. 1(A3-A6)). The lymphoid proliferation in the right eye was smaller and less dense than the left; however, it showed similar morphologic features, both of which very much resemble that of grade $3 \mathrm{~B}$ type of follicular lymphoma in adult population (Fig. 1(A3-A6)). On immunohistochemical analysis of the left eye lesion, the atypical follicles express CD20, CD10, BCL6, MYC (subset, $60 \%$ ), IgM, MUM1 (subset, $50 \%$ ) and are completely negative for BCL2. Ki67 stain highlights a proliferation rate of over $90 \%$ (Fig. 2(B1-B5)). CD21 immunohistochemical stain highlighted an expanded and distorted follicular dendritic meshwork (Fig. 2(B3)).

FISH studies for $t(14 ; 18) \operatorname{IgH} / B C L 2$ fusion, BCL6, and $c M Y C$ gene rearrangements showed no abnormalities. Molecular studies for B cell immunoglobulin heavy chain gene $(\operatorname{IgH})$ rearrangement detected a clonal population (Fig. 2(B6)), while B cell immunoglobulin kappa light chain $(I g K)$ gene clonality assay was negative.

The overall findings of the nodular growth pattern, expended and distorted follicles with CD10/BCL-6 positive large cell proliferation with high proliferative index, along with clonal $\mathrm{IgH}$ gene rearrangement were consistent with a diagnosis of PFL.

\section{Discussion}

Non-Hodgkin lymphomas in the pediatric population are usually aggressive diseases clinically like lymphoblastic lymphoma, anaplastic large cell lymphoma, Burkitt lymphoma, and diffuse large B cell lymphoma, all of which have been reported in the literature to involve the conjunctiva [7-10]. Lymphomas involving the conjunctiva and ocular adnexa in adults, however, are most commonly extranodal marginal zone lymphoma of mucosa-associated lymphoid tissue (MALT) type [10]. Conjunctival MALT lymphomas have also been rarely reported in children [11]. Follicular lymphomas are rarely reported in the conjunctiva in adults [10] and are extremely rare in the pediatric population [10]. PFL is a distinct subtype of follicular lymphoma described in the World Health Organization, 2008 edition [1], and is characteristically seen in children and young adults. 
Fig. 2 Immunophenotypic characterization of the large expanded follicles: they are positive for $\mathrm{CD} 20(B 1)$ and $\mathrm{CD} 10$ (B2) in an expanded and distorted follicular dendritic meshwork identified on CD21 stain (B3). The neoplastic cells are also positive for IgM (B4) and MYC protein (B5). Molecular studies detected a clonal $\mathrm{IgH}$ gene rearrangement $(B \sigma)$
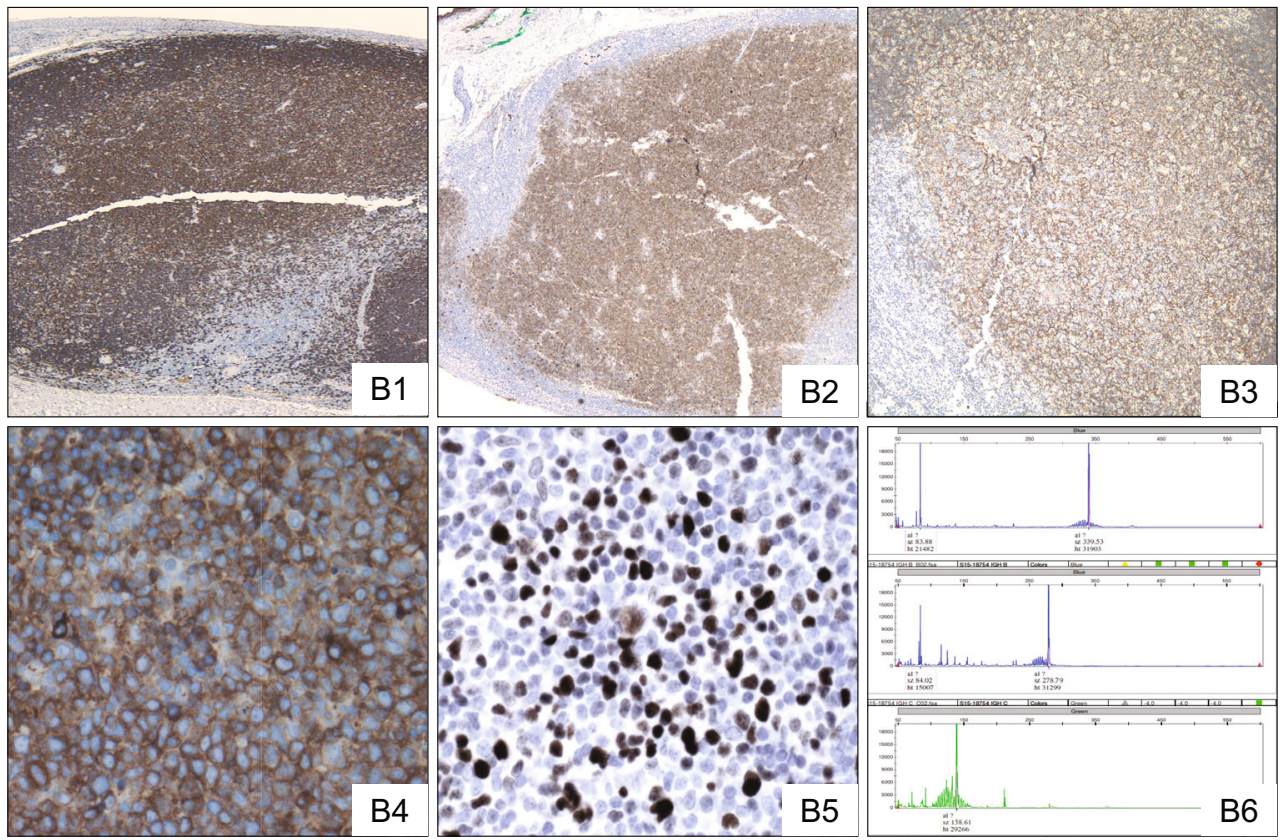

PFL are usually seen in male patients and most commonly involves the head and neck region-cervical lymph nodes, and Waldeyer ring, other peripheral lymph nodes and has also been well reported in the testis [2]. They typically lack $t(14 ; 18) \operatorname{IgH} / B C L 2$ fusion characteristically seen in majority of adult follicular lymphomas, and often do not express BCL2 protein. Morphologically, they show large, expanded follicles that are irregular or serpiginous in shape. Majority of them have high-grade cytologic features, equivalent of grade 3 in adult follicular lymphoma based on proportion of centroblast. Children with PFL usually have localized or early stage disease and have an indolent clinical behavior. It should be noted that adult type follicular lymphomas with $t(14 ; 18) I g H / B C L 2$ fusion and BCL-2 protein expression may rarely occur in the pediatric population, which are usually low grade (grade 1-2) [2]. These should not be designated as PFL due to differing clinical behavior and disease pathogenesis.

The pathogenesis of PFL is currently unclear. Over $90 \%$ of reported cases showed clonal $\operatorname{IgH}$ gene rearrangement and in cases lacking the former, showed clonal $\operatorname{IgK}$ gene rearrangement [2]. A subset of cases expressed MUM-1 protein, including few showing IRF4 gene rearrangement and IgH/IRF4 fusion [2]. Interestingly, majority of the MUM1 positive cases involved the Waldeyer ring [2]. MYC protein expression has not been previously studied in PFL, and expression of MYC protein in our case is a novel finding, suggesting the MYC pathway playing a possible role. Interestingly, although MYC protein expression in adult follicular lymphoma is thought to show an aggressive clinical course [12], PFL is likely an exception. We also identified strong expression of IgM in the neoplastic cells; a finding also seen in a prior case report [13] and reported previously in subset of adult follicular lymphomas [14], which suggests possible defective class switch recombination, characteristics similar to IgM + memory B cells [15] or malignant transformation occurring in the naïve $B$ cell stage. This hypothesis needs to be tested in a larger series of cases with additional molecular studies.

The most significant diagnostic challenge in PFL is differentiating it from florid follicular hyperplasia, especially in areas with prominent lymphoid tissue like Waldeyer ring, commonly occurring in childhood population. Rare cases of follicular hyperplasia have also been reported to show presence of clonal CD10-positive cells [16]. The presence of numerous tingible-body macrophages, lack of typical $(14 ; 18)$ $I g H / B C L 2$ fusion, and lack of BCL2 protein expression adds to the diagnostic dilemma. The presence of architectural atypia with expanded/serpiginous follicles and cytologic atypia with increased numbers of large atypical monomorphic cells should raise suspicion of PFL. High clinical and morphologic suspicion should trigger ancillary studies. Immunohistochemical findings like MUM1, MYC, and IgM positivity are supportive of the diagnosis. B cell gene rearrangement studies are extremely useful as over $90 \%$ cases show a clonal gene rearrangement [2].

MALT lymphomas, being the most common lymphoma in the ocular adnexa, is a differential diagnosis to consider, especially in cases with a nodular architectural pattern due to marked follicular colonization and expression of IgM and MUM1. MALT lymphomas usually are composed of smallsized cells, or an admixture of small and larger cells, with a CD10 negative, BCL2 positive immunophenotype. CD10 expression has rarely been reported in low-grade MALT lymphomas [17]. On the other hand, PFLs are usually of high-grade 
morphology with increased larger-sized cells (grade 3 ) and are usually CD10 positive, BCL2 negative in majority of cases. FISH studies for MALT1 gene rearrangement may also be helpful and considered in difficult cases.

Translocations activating IRF4 oncogene like IGH/IRF4 fusion was recently identified as a distinct molecular subgroup of germinal center derived B cell lymphomas including diffuse large B cell lymphomas and grade 3 follicular lymphomas [18]. These are seen predominantly in the head and neck region of children and young adults, show IRF4 and BCL6 gene rearrangements, express MUM1 and BCL6 proteins, and lack $t(14 ; 18) I G H / B C L 2$ fusion. Given that majority of reported extranodal PFLs in the head and neck region show IRF4 aberrations and MUM1 expression [2], it is possible that this subset of PFL (including our case) and IGH/IRF4 positive follicular and diffuse large $\mathrm{B}$ cell lymphomas represent lesions in the same disease spectrum. Nodal and testicular PFLs on the other hand are less often reported to show IRF4 and BCL6 gene rearrangements, and may be biologically distinct [19].

PFL shows an indolent clinical behavior, in spite of the morphologic features equivalent to grade 3 adult follicular lymphoma. Even in the presence of concurrent diffuse large B cell lymphoma, they show very good clinical outcomes with therapy [20]. There is no current consensus on the optimal clinical management of PFL. Majority of localized lesions are treated by surgical excision with close follow up. However, Rituxan with or without adjuvant radiation is used for multifocal/disseminated disease. A multi-agent systemic chemotherapy like R-CHOP is considered for refractory or relapsed extensive disease or with the presence of concurrent diffuse large B cell lymphoma. The overall survival is excellent with very low risk of recurrence [20-22].

\section{Compliance with ethical standards}

Conflict of interest The authors declare that they have no conflict of interest.

\section{References}

1. Harris NL, Swerdlow SH, Jaffe ES et al (2008) Follicular lymphoma. In: Swerdlow SH, Campo E, Harris NL et al (eds) WHO Classification of Tumours of Haematopoietic and Lymphoid Tissue, 4th edn. IARC Press, Lyon, pp 220-226

2. Liu Q, Salaverria I, Pittaluga S, Jegalian AG, Xi L, Siebert R, Raffeld M, Hewitt SM, Jaffe ES (2013) Follicular lymphomas in children and young adults: a comparison of the pediatric variant with usual follicular lymphoma. Am J Surg Pathol 37(3):333-343

3. Gaffar M, Thebpatiphat N, Przygodzki R, Jacobs S, Miller MM (2010) Primary follicular lymphoma of the conjunctiva in a 6year-old child. J AAPOS 14(6):538-540

4. Perry LJ, Jakobiec FA, Rubin PA (2012) Conjunctival pediatric follicular lymphoma. Arch Ophthalmol 130(7):941-943
5. Taghipour Zahir S, Miratashi SA, Nazemian M, Zand S (2013) Primary follicular lymphoma of the conjunctiva in a 12 year-old male. Iran J Ped Hematol Oncol 3(2):83-85

6. Wall PB, Traboulsi EI, Hsi ED, Singh AD (2015) Bilateral conjunctival follicular lymphoma in a child. J AAPOS 19(2):183-185

7. Campagnoli MF, Parodi E, Linari A, D'alonzo G, Onnis E, Farinasso L (2003) Conjunctival mass: an unusual presentation of acute lymphoblastic leukemia relapse in childhood. J Pediatr 142(2):211

8. Kirwan C, Ngan BY, Halliday W, Alexander S, Ali A (2013) Primary conjunctival anaplastic large cell lymphoma in a child. J AAPOS 17(4):437-439

9. Weisenthal RW, Streeten BW, Dubansky AS, Hutchison RE, Pecora JL (1995) Burkitt lymphoma presenting as a conjunctival mass. Ophthalmology 102(1):129-134

10. Ferry JA, Fung CY, Zukerberg L, Lucarelli MJ, Hasserjian RP, Preffer FI, Harris NL (2007) Lymphoma of the ocular adnexa: a study of 353 cases. Am J Surg Pathol 31(2):170-184

11. Tiemann M, Häring S, Heidemann M, Reichelt J, Claviez A (2004) Mucosa-associated lymphoid tissue lymphoma in the conjunctiva of a child. Virchows Arch 444(2):198-201

12. Christie L, Kernohan N, Levison D, Sales M, Cunningham J, Gillespie K, Batstone P, Meiklejohn D, Goodlad J (2008) C-MYC translocation in $\mathrm{t}(14 ; 18)$ positive follicular lymphoma at presentation: An adverse prognostic indicator? Leuk Lymphoma 49(3): 470-476

13. Karnik T, Ozawa MG, Lefterova M, Luna-Fineman S, Alvarez E, Link M, Zehnder JL, Arber DA, Ohgami RS (2015) The utility of IgM, CD21, HGAL and LMO2 in the diagnosis of pediatric follicular lymphoma. Hum Pathol 46(4):629-633

14. Zheng Y, Zhou X, Xie J, Zhu H, Zhang S, Zhang Y, Wei X, Yue B (2014) IgM expression in paraffin sections distinguishes follicular lymphoma from reactive follicular hyperplasia. Int J Clin Exp Pathol 7(6):3264-3271

15. Seifert M, Kuppers R (2009) Molecular footprints of a germinal center derivation of human $\operatorname{IgM}+(\operatorname{IgD}+) \mathrm{CD} 27+\mathrm{B}$ cells and the dynamics of memory B cell generation. J Exp Med 206:2659-2669

16. Kussick SJ, Kalnoski M, Braziel RM, Wood BL (2004) Prominent clonal B-cell populations identified by flow cytometry in histologically reactive lymphoid proliferations. Am J Clin Pathol 121(4): 464-472

17. Millar EK, Waldron S, Spencer A, Braye S (1999) CD10 positive thyroid marginal zone non-Hodgkin lymphoma. J Clin Pathol 52(11):849-850, Review

18. Salaverria I, Philipp C, Oschlies I, Kohler CW, Kreuz M, Szczepanowski M, Burkhardt B, Trautmann H, Gesk S, Andrusiewicz M, Berger H, Fey M, Harder L, Hasenclever D, Hummel M, Loeffler M, Mahn F, Martin-Guerrero I, Pellissery S, Pott C, Pfreundschuh M, Reiter A, Richter J, Rosolowski M, Schwaenen C, Stein H, Trümper L, Wessendorf S, Spang R, Küppers R, Klapper W, Siebert R, Salaverria I, Philipp C, Oschlies I, Kohler CW, Kreuz M, Szczepanowski M, Burkhardt B, Trautmann H, Gesk S, Andrusiewicz M, Berger H, Fey M, Harder L, Hasenclever D, Hummel M, Loeffler M, Mahn F, Martin-Guerrero I, Pellissery S, Pott C, Pfreundschuh M, Reiter A, Richter J, Rosolowski M, Schwaenen C, Stein H, Trümper L, Wessendorf S, Spang R, Küppers R, Klapper W, Siebert R, Molecular Mechanisms in Malignant Lymphomas Network Project of the Deutsche Krebshilfe, German High-Grade Lymphoma Study Group, Berlin Frankfurt-Münster-NHL trial group (2011) Translocations activating IRF4 identify a subtype of germinal center derived B-cell lymphoma affecting predominantly children and young adults. Blood 118(1):139-147

19. Louissaint A Jr, Ackerman AM, Dias-Santagata D, Ferry JA, Hochberg EP, Huang MS, Iafrate AJ, Lara DO, Pinkus GS, Salaverria I, Siddiquee Z, Siebert R, Weinstein HJ, Zukerberg 
LR, Harris NL, Hasserjian RP (2012) Pediatric-type nodal follicular lymphoma: an indolent clonal proliferation in children and adults with high proliferation index and no BCL2 rearrangement. Blood 120(12):2395-2404

20. Oschlies I, Salaverria I, Mahn F, Meinhardt A, Zimmermann M, Woessmann W, Burkhardt B, Gesk S, Krams M, Reiter A, Siebert R, Klapper W (2010) Pediatric follicular lymphoma - a clinicopathological study of a population-based series of patients treated within the Non-Hodgkin's Lymphoma-Berlin-Frankfurt-Munster (NHL-BFM) multicenter trials. Haematologica 95(2):253-259

21. Kumar R, Galardy PJ, Dogan A, Rodriguez V, Khan SP (2011) Rituximab in combination with multiagent chemotherapy for pediatric follicular lymphoma. Pediatr Blood Cancer 57(2):317-320

22. Perkins SL, Gross TG (2011) Pediatric indolent lymphoma - would less be better? Pediatr Blood Cancer 57(2):189-190 